\title{
MONITORING COVID-19 IS LIKE INSTRUMENT FLYING
}

\author{
Petar V. Kočovića ${ }^{\text {, Zoran V. Kočović }}{ }^{b}$, Vladimir P. Kočovićc \\ a University Union "Nikola Tesla", School for Information Technology \\ and Engineering, Belgrade, Republic of Serbia, \\ e-mail: petar.kocovic@fpsp.edu.rs, corresponding author, \\ ORCID iD: (iohttps://orcid.org/0000-0001-8289-1385 \\ ${ }^{b}$ Omni Logika, Belgrade, Republic of Serbia, \\ e-mail: impulsıxigmail.com, \\ ORCID iD: (Dhttps://orcid.org/0000-0003-4815-0350 \\ c IGT, Belgrade, Republic of Serbia, \\ e-mail: kocovic.vladimir@gmail.com, \\ ORCID iD: (1)https://orcid.org/0000-0002-3943-6341
}

DOI: 10.5937/vojtehg68-26557; https://doi.org/10.5937/vojtehg68-26557

FIELD: Mathematics

ARTICLE TYPE: Original Scientific Paper

\section{Summary:}

Introduction/purpose: To monitor the COVID-19 epidemic in every single country in the world, this team has developed a specific system that consists of the following diagrams and mathematical models: a) epidemiological curve, b) histogram of infected people, c) histogram of infected people in last five days, d) double logarithmic curve for monitoring the speed of the epidemic, e) epidemic pipeline and f) Gaussian and Boltzmann S curves. As it is shown in this paper, monitoring an epidemic is like flying a plane using instruments.

Methods: The most complex model is the calculation of the truncated Gaussian curve, and this model will be discussed in more detail in this paper. Also, there is time coincidence between the Gaussian curve and the S-curve. The input data were found in the World Health Organization's daily reports. The full set of data consists of the Gaussian curve, the double logarithmic curve, and the epidemic curve. In some cases, using only one of the three specified parameters is not enough.

Results: To prove a specified methodology, the paper has dozens of results in the form of diagrams.

Conclusion: The Gaussian curve was formed, and the end of the epidemic was calculated. But, in some cases, the epidemic curve was not wellformed (the end of the epidemic is not clear since many countries did not declare the number of recovered people in a proper way). This is the reason why we must include a flow of the double logarithmic curve into consideration. Only a combination of these three diagrams can give the right insight into the right decision.

Keywords: COVID-19, Gaussian curve, S-curve. 


\section{Introduction}

This paper aims to describe a set of mathematical models for decision making about critical decisions in the epidemic. Besides medical decisions, the economic impact on each country, state, and territory is also very important. How long to close some industries, what will be the impact on jobs, and dismissal of workers are the key ones. This team has developed software for monitoring all specified data daily for the top 50 countries. (Kočović et al, 2020)

The main curve is epidemiological (EpiCurve). The epidemiological curve can be shown with the following formula:

$$
\text { Still infected }=\text { totally infected }- \text { death }- \text { recovered }
$$

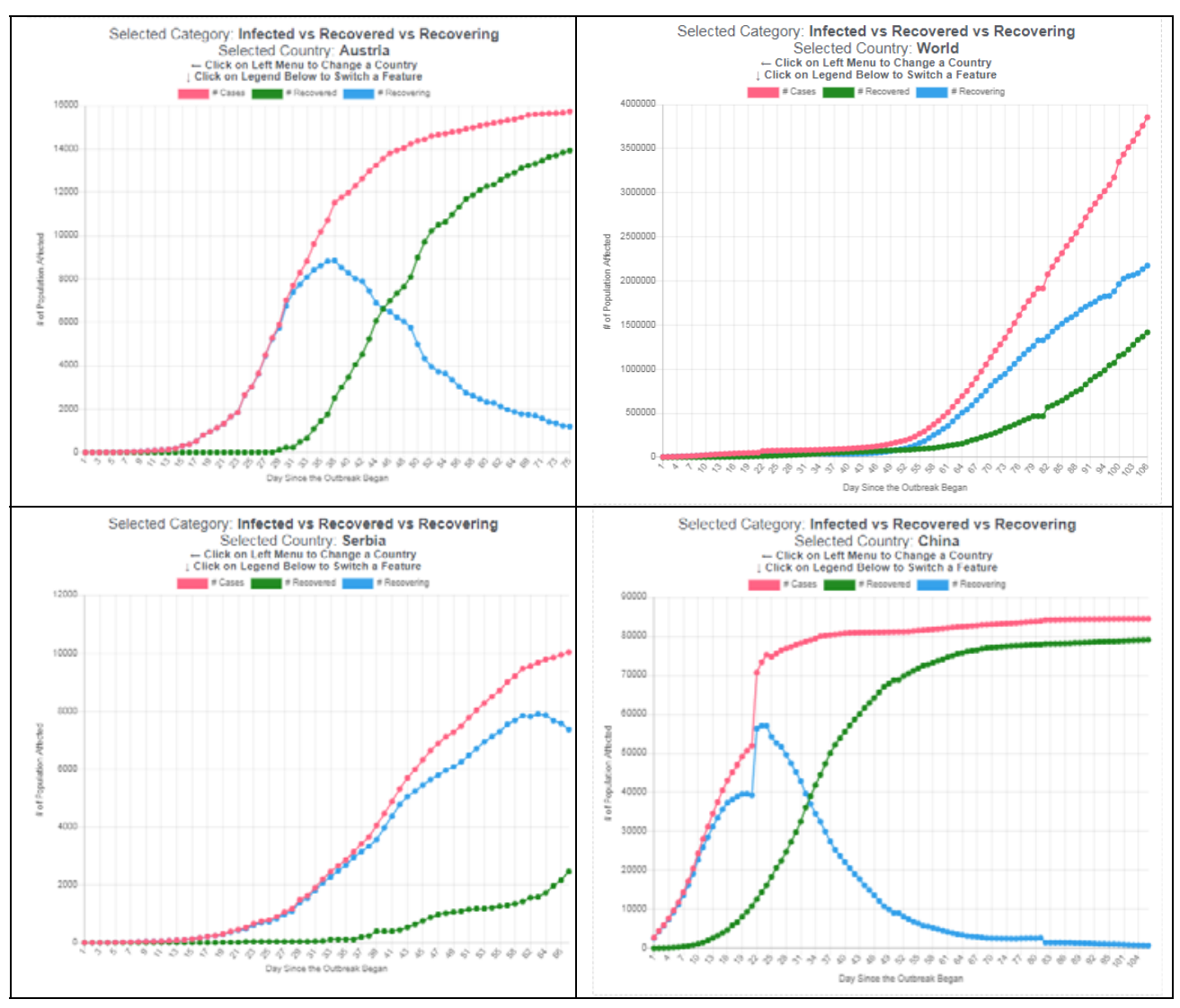

Figure 1 - EpiCurves a) Austria, b) World, c) Serbia, and d) China Puc. 1 - Эпидемиологическая кривая а) Австрия, б) мир, в) Сербия и г) Китай Слика 1 - Епидемиолошка крива: а) Аустрија, б) свет, в) Србија и г) Кина 
Figure 1 is showing the EpiCurves for three territories and the whole world. The epidemiological curves are related to single countries.

The meanings of the symbols in the figures are:

- \#Cases - the total number of the infected from the beginning of the epidemic in a particular country

- \#Recovered - the number of people recovered from the beginning of the epidemic in a particular country

- \#Recovering - the number of people calculated from formula (1)

As we can see in Figure 1, the curve(s) of the \#Recovering is(are) the EpiCurve. In the cases of 1a) Austria and 1d) China, the curves are closed. In two other examples, the curves are in the phase of the initial (1b) World) or the middle phase (1c). All four examples show that \#Cases follow the shape of the letter "S" and have the name of the $S$ (or Sigmoid) curve.

These curves are real, so we cannot make any forecasts from these curves. Instead, mathematical modeling and forecasting techniques are used in these calculations.

\section{Histograms and 5-day histograms}

The curves denoted as \#Recovering look like Gaussian curves. But there is one exception between the uses of a Gaussian distribution when a full curve is formed. In epidemic modeling, there are new data on the infected every day. For these purposes, histograms and 5-day histograms have been developed (Mann, 1994).

Histograms represent the number of infected per day ${ }^{1}$. Even if they do not look like a Gaussian distribution, in many cases we can fit them within the Gaussian curve. Figure 2 shows two examples of the histograms for COVID-19 cases.

In Figure 2a), the case of Brazil shows that a Gaussian distribution is not visible. The same situation is in Figure $2 b$ ).

Also, a short 5-day histogram can represent good or bad trends. Good trends are when the number of the infected decreases in five consecutive days and bad trends are the opposite - when in five consecutive days the number of the infected grows. Figure 3 shows two examples - Germany and Japan.

Most of the 5-day trends show intermediate results. Notice that if there is just one day with a very high number of the infected- this will prolong the recovery period.

${ }^{1}$ Data about COVID-19 can be found in the separate reports on the web site of the World Health Oranization (World Health Organzation, 2020). 


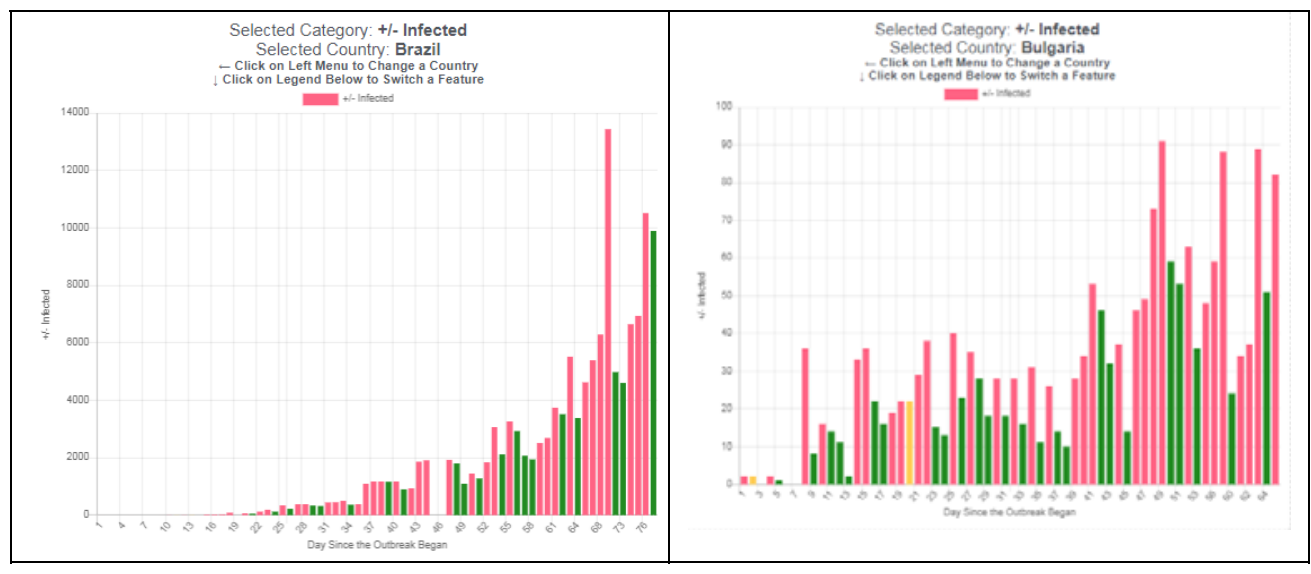

Figure 2 - Histograms a) Brazil, b) Bulgaria

Puc. 2 - Гистограмма а) Бразилия, б) Болгария

Слика 2 - Хистограм: а) Бразил, б) Бугарска

This 5-day trend represents a very good visual form for simplifying the monitoring of the epidemic. In the period of the epidemic growth, there are more red bars.

The histograms are basic tools for Gaussian and Sigmoid/S-curves. However, significant assumptions were made for both of them.

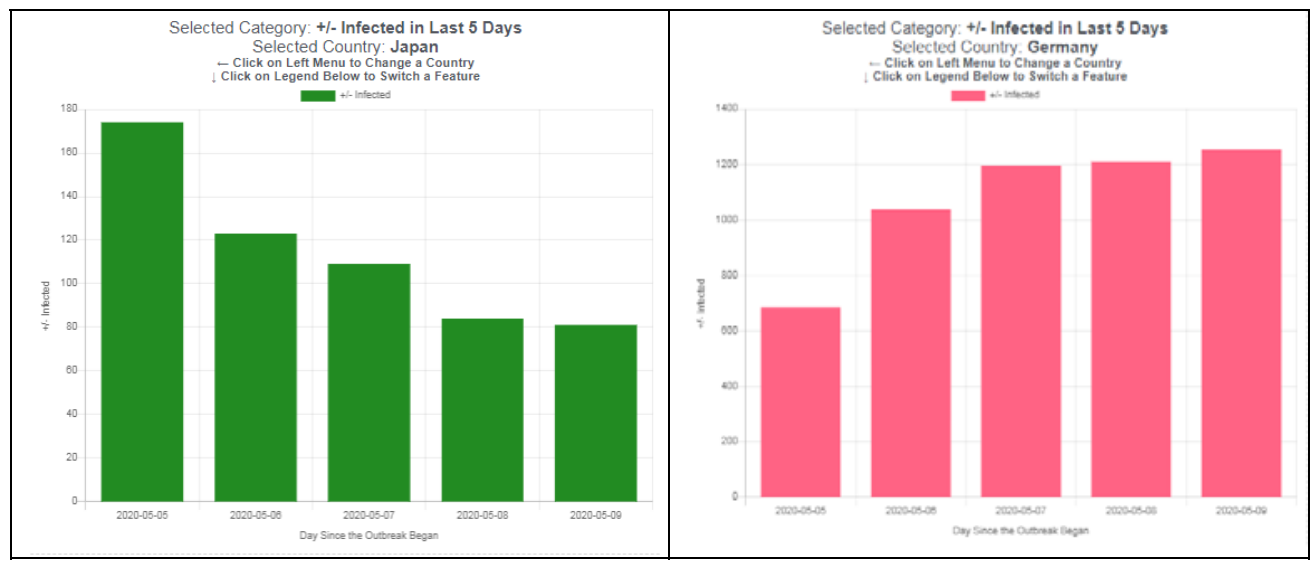

Figure 3 - Five-day trends- a) good - Japan, and b) bad - Germany. Both of them are in the period May 5 - May 9, 2020

Рис. 3 - Пятидневный тренд - а) положительный - Япония и б) отрицательный Германия. Оба тренда за период с 5 по 9 мая 2020 года.

Слика 3 - Петодневни тренд: а) добар - Јапан и б) лош - Немачка. Оба тренда односе се на период 5-9. мај 2020. године 


\section{Gaussian distribution}

For defining Gaussian curves (Gauss, 1809), (Stahl, 2006), the standard Laplace-Gauss formula is used (2) with a few modifications (Laplace, 1774):

$$
f(x)=\frac{1}{\sigma \sqrt{2 \pi}} e^{-\frac{1}{2}\left(\frac{x-\mu}{\sigma}\right)^{2}}
$$

For calculating this curve, the standard error was used. The maximum number of iterations is 1,000 for these calculations.

The infections start outgrowing exponentially at first, then whatever response the host country enacts, after some time, new infections go back to near zero. At least this is the back-of-the-envelope theory, developed by Enrico Fermi ${ }^{2}$. There are undoubtedly better models, but the Gaussian model was used as the first shot in this mathematical model.

The Gaussian model is defined by only three parameters: $N, \mu$, and $\sigma$, and looks like this:

- $\mathrm{N}$ is the infection rate at its peak, the midpoint of the epidemic.

- $\mu$ is the date of the peak infection rate, and

- $\sigma$ controls the width, the period of time the pandemic is experienced by the country.

Figure 4 shows the statements given above:

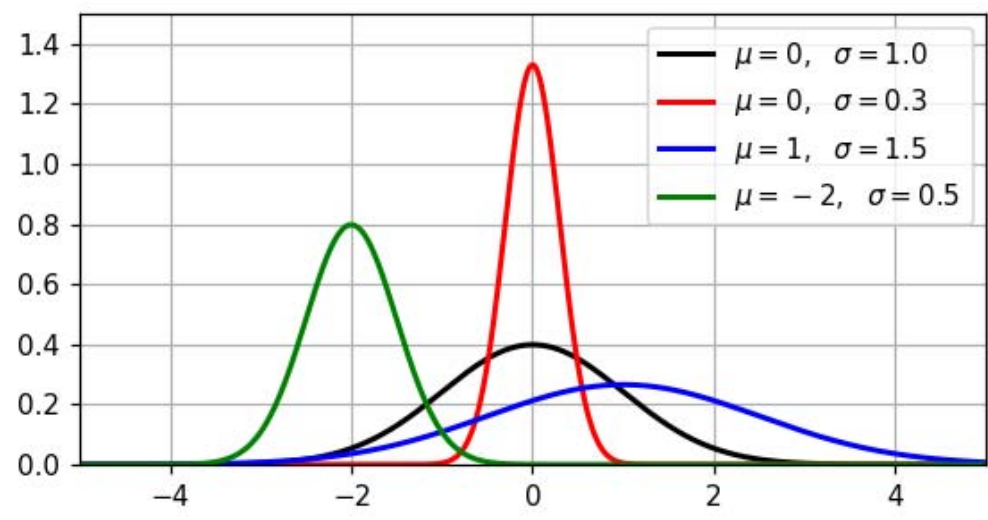

Figure 4 - The Normal, or the Gaussian curve

Puc. 4 - Кривая нормального распределения Гаусса Слика 4 - Нормална или Гаусова крива

\footnotetext{
2 The term Back of the envelope calculation is a rough calculation. It is more than a guess, but less than a mathematical proof.
} 


\section{Using the model}

The alternative names for the Gaussian distribution are 6 SIGMA or LEAN 6 SIGMA. However, the model was extended adding two extra periods. Instead of 6SIGMA, 8 SIGMA model was used, Figure 5.

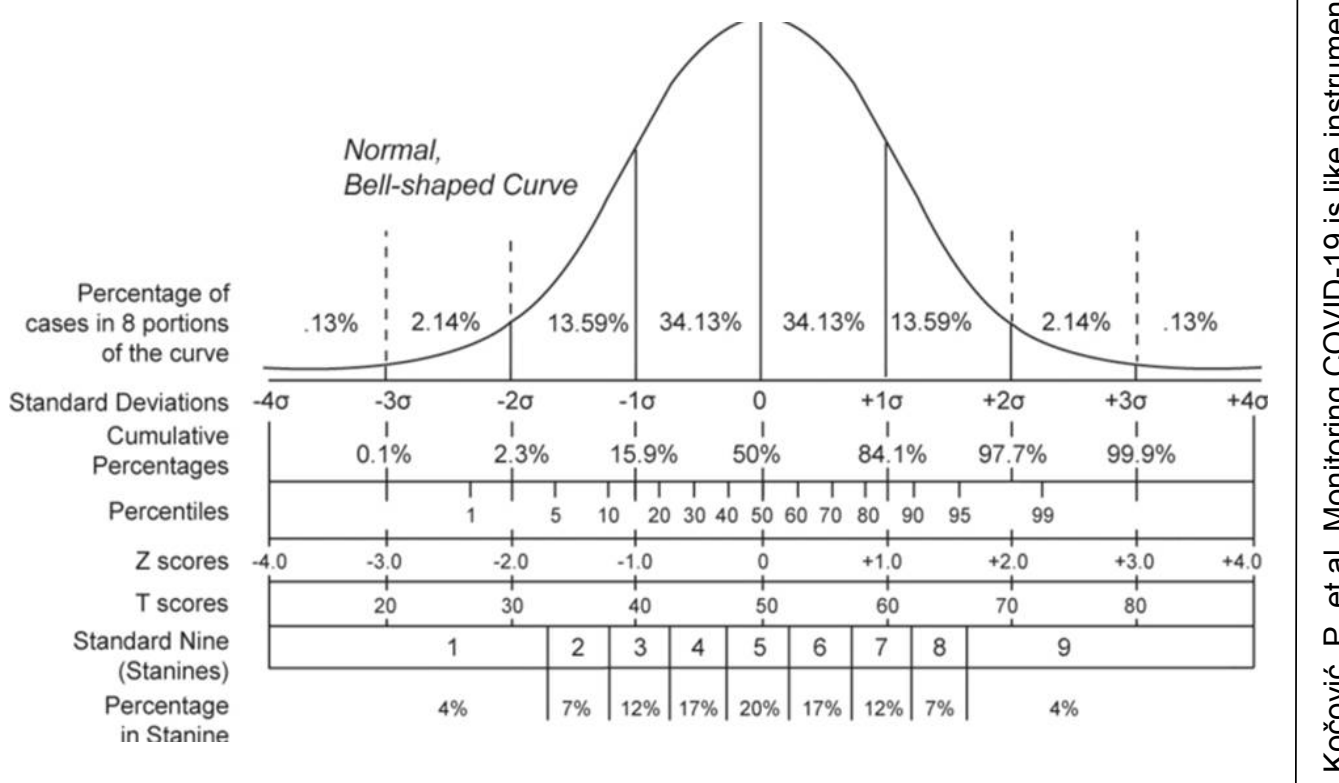

Figure 5 - Gaussian distribution extended to 8 SIGMA

Puc. 5 - Кривая распределения Гаусса расширена за 8 СИГМ

Слика 5 - Гаусова расподела проширена на 8 СИГМА

Why is an extension to eight periods important? Because the intersections between the Gaussian curve and the vertical lines that present SIGMAs are the places for decision making. Figure 6 represents this scenario (Kočović, 2020).

For calculating the Gaussian curve and the Sigmoid (S) curve, programming language Python was used. Figure 7 shows the examples for the following countries: Austria, Peru, Hungary, and Serbia.

A mathematical model can calculate the whole distribution if histograms are covered with more than $50 \%$ of the data. The algorithm calculates distribution if the minimum 3 SIGMA conditions are fulfilled, and there are no extreme peaks in one day. Otherwise, the Gaussian curve cannot be formed. 


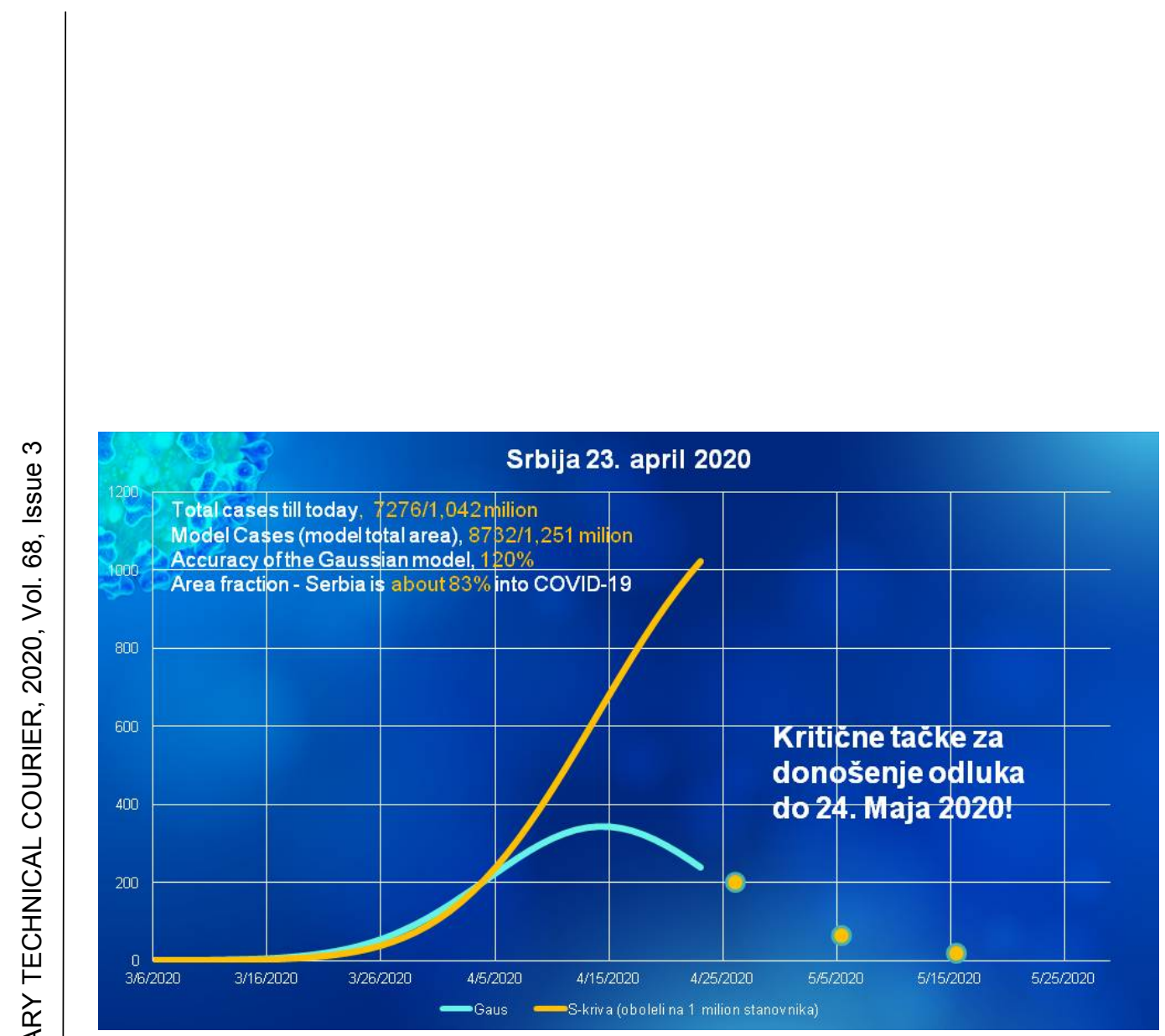

Figure 6 - Truncated Gaussian curve for Serbia, on April 23, 2020. At that time, the forecasted end of the epidemic was May 24, 2020. The dots represent the dates when critical decisions should be made.

Puc. 6 - Усеченная кривая Гаусса, относящаяся к Сербии, на 23 апреля 2020 года. По прогнозу, произведенному в тот день, эпидемия должна была остановится 24 мая 2020 года. Точками обозначены даты, когда должны были быть приняты критические решения.

Слика 6 - Делимична Гаусова крива за Србију на дан 23. априла 2020, када је предвиђено да ће знавични крај епидемије у Србији бити 24. маја 2020. године.

Тачке представљају дане када је требало донети критичне одлуке.

Figure 7 represents four different countries with four different histograms and Gaussian curves. Given $\mathrm{N}$ and $\sigma$, the total area under the model curve is:

Total Area $=N \sigma \sqrt{2 \pi}$

Here are the results for Serbia for May 10, 2020.

Total cases until that day, 10114.0

Model Cases (model total area), 10374

Accuracy of the Gaussian model, 103\%

Area fraction - Serbia is about $97 \%$ into COVID-19

The forecasted day of the $7 \sigma$ is May 26, 2020.

As it is shown, the model can predict, mathematically, the end of the epidemic. But, one thing is mathematics, another is real life. 


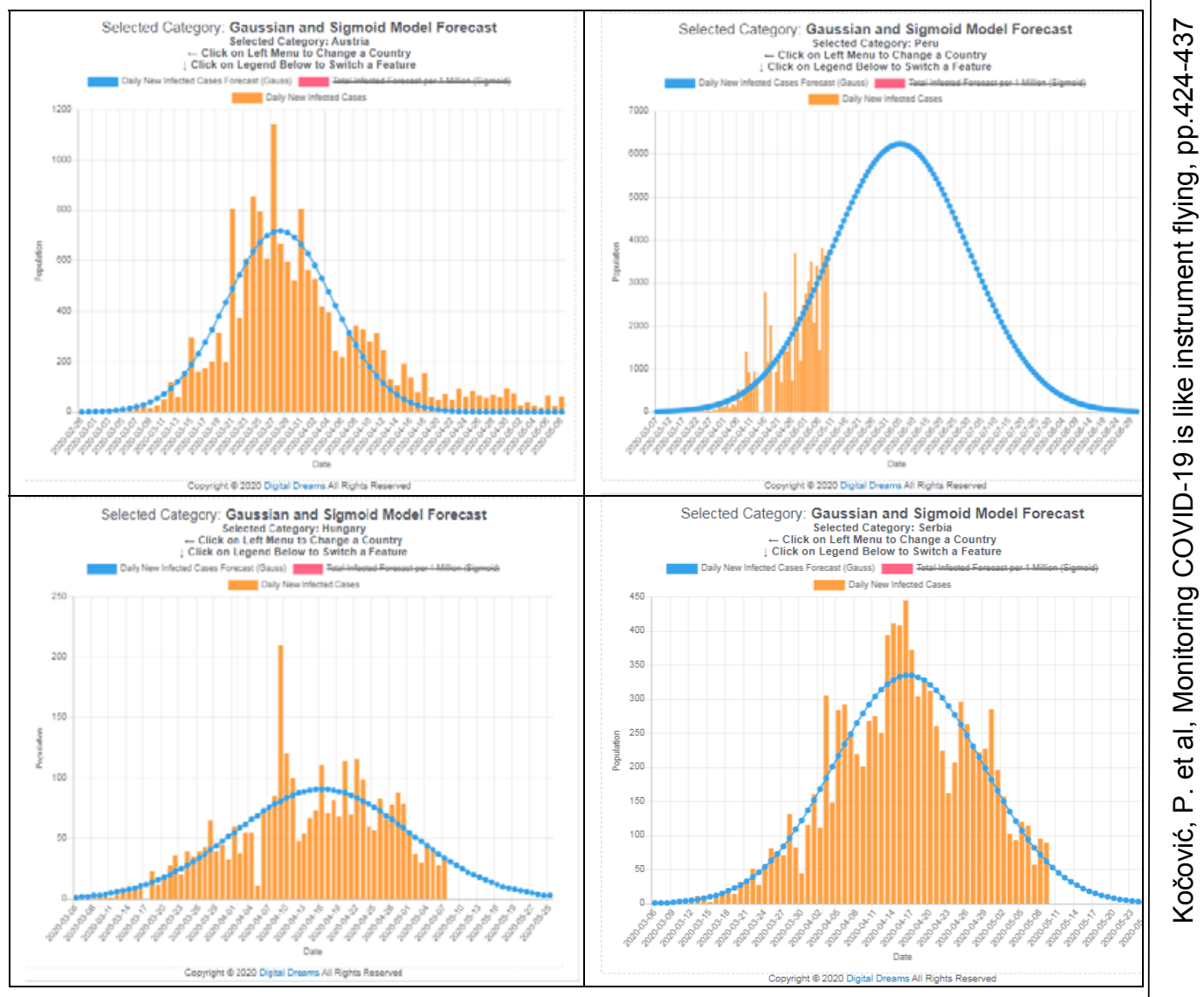

Figure 7 - Gaussian curve used for predicting the end of the epidemic per country: a) Austria, b) Peru, c) Hungary, and d) Serbia

Puc. 7 - Кривая Гаусса, относящаяся к кониу эпидемии по государствам: а) Австрия, б) Перу, в) Венгрия и г) Сербия

Слика 7 - Гаусова крива коришћена за крај епидемије по државама: а) Аустрија, б) Перу, в) Мађарска и д) Србија

\section{Link between the Gaussian curve and the Sigmoid Curve}

As it was shown in Figure 1, the EpiCurve is real, but we always need forecasts. To link mathematics with real life, the Sigmoid or S-curve was used. On the other hand, the authors found a link between Gaussian and Boltzmann or Sigmoid (S) curves (Reséndiz-Muñoz et al, 2017, pp.1043-1047). In Figure 8, the link between the Gaussian curve and the S-curve was shown. 
The reader can see that the starting points, the endpoints, and the slope points are shown on the curves. The vertical line is the day of the epidemic. Once again - compare \#Cases in Figure 1, and the S-curve in Figure 8.

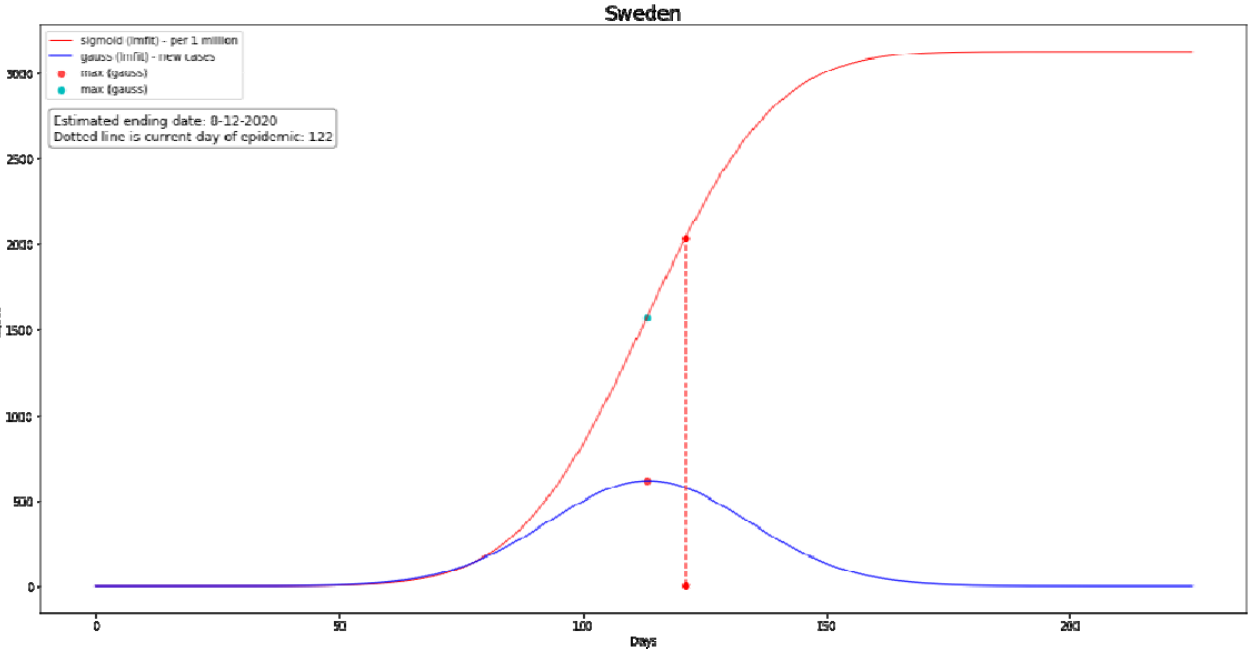

Figure 8 - COVID-19 Gaussian curve and S-curve for Sweden, on May $1^{\text {st }}, 2020$ Puc. 8 - Кривая COVID-19 по модели кривой Гаусса и C-кривой, относящаяся к Швеции на 1 мая 2020 года.

Слика 8 - Криве за COVID-19 по моделу Гаусове криве и C-криве за Шведску, 1. маја 2020. године

\section{Final Step - fine-tuning}

The Gaussian curve can calculate the date of the end of the epidemic with a probability of $99.9996 \%$. This means that the chances are ONE in a MILLION for citizens to become ill with COVID-19 after the Gaussian distribution has ended. For Serbia - this number is 7 (sometimes this number will be 20 , sometimes 0 ). For example, for Mexico, this number is 129 .

However, for better decision making, a double logarithmic curve model was developed. Four examples are shown in Figure 9.

The $x$-axis contains the total number of the infected. On the $y$-axis, there are the numbers of the infected in the last 7 days, for every day in the epidemic. Both axes are in the logarithmic scale. The days are shown in the trajectory, so this is the third dimension presented on the curve (Kočović, 1998). 
Why is this curve important?

Even in the case that the condition of 7SIGMA is fulfilled on the Gaussian curve, on the double log curve it is not. Let us compare the data for Serbia: Figure 7d for the Gaussian curve and Figure 9a for the double logarithmic curve. In Figure $7 d$, it seems that the epidemic was almost finished. In Figure 9a, we can see that this is not the case. Therefore, the double logarithmic curve is used for fine-tuning.

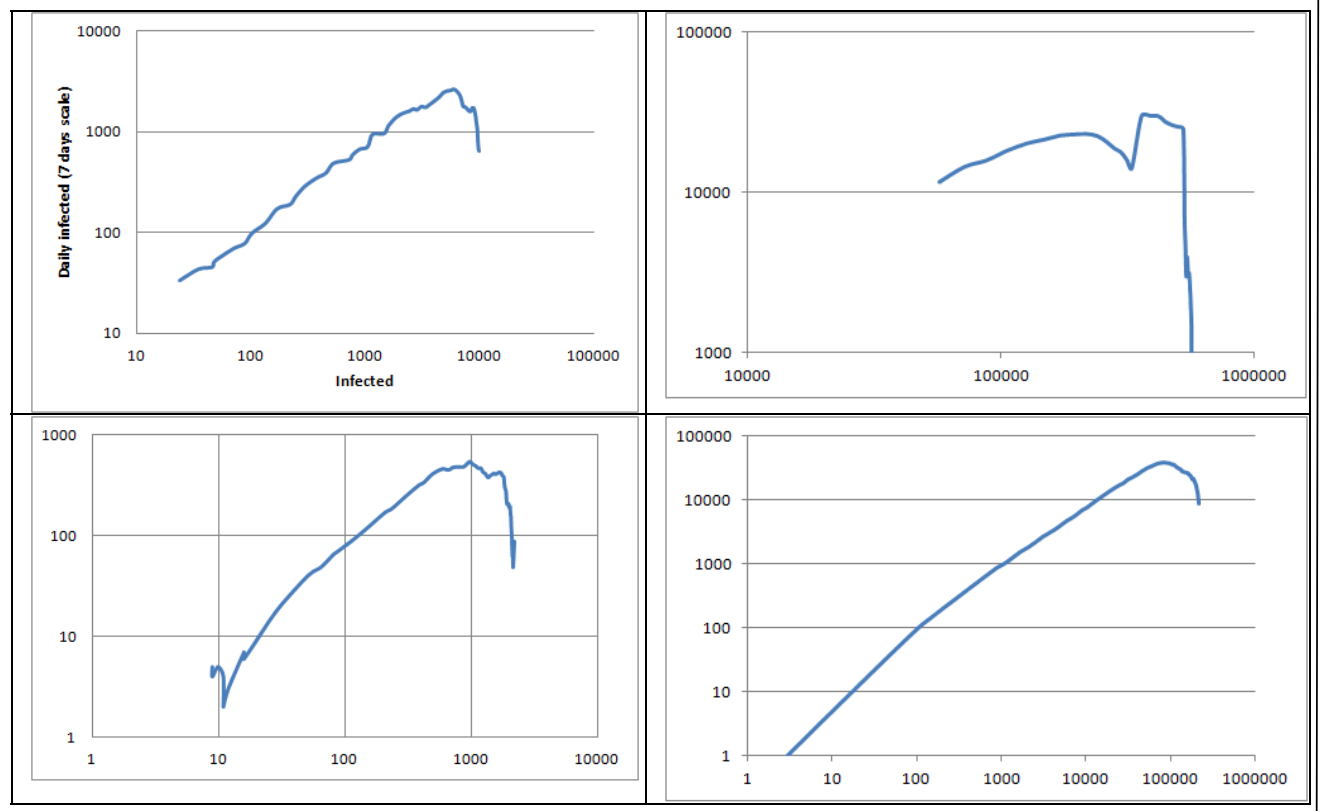

Figure 9 - Double logarithmic curve for a) Serbia, b) China, c) Croatia, and d) Italy, on May 10,2020

Pис. 9 - Кривая в двойном логарифмическом масштабе, относящаяся к: а) Сербии, б) Китаю, в) Хорватии и г) Италии, на 10 мая 2020 г.

Слика 9 - Двострука логаритамска крива за: а) Србију, б) Кину, в) Хрватску и д) Италију, 10. маја 2020. године

\section{Conclusion}

For this research, a model presented in (Kočović et al, 2020) was developed. Further development of the epidemic/pandemic is going to link the Gaussian curve with the economic development of the countries. A smaller 8SIGMA means a shorter period of the epidemic, and eventually a higher peak. This means that more medical staff will be needed. If the curve is flattened - the duration will be longer and a possible number of the infected and the dead will be smaller. Some countries, such are United Kingdom (Flaxman et al, 2020), (Ferguson et 
al, 2020), USA (McKinsey \& Company, 2020), and Sweden used this model of free infection. But finally, they had to change their initial decision.

\section{References}

Ferguson, N.M., \& et al. 2020. Impact of non-pharmaceutical interventions (NPIs) to reduce COVID19 mortality and healthcare demand. Report 9, Imperial College London, pp.1-20. Available at: https://doi.org/10.25561/77482.

Flaxman, S., \& et al. 2020. Estimating the number of infections and the impact of non-pharmaceutical interventions on COVID-19 in 11 European countries. Report 13, Imperial College London, pp.1-35. Available at: https://doi.org/10.25561/77731.

Gauss, C.F. 1809. Theoria motus corporum coelestium in sectionibus conicis solem ambientium. Hamburgi: sumtibus Frid. Perthes et I. H. Besser (in Latin). Available at: https://doi.org/10.3931/e-rara-522.

Kočović, P. 1998. Geometrijsko modeliranje, vol 1. Belgrade: Petar Kočović (in Serbian).

Kočović, P. 2020. Petar Kočović - Gausova kriva i prognoza COVID-19 epidemije [online] Available

https://www.youtube.com/watch?v=4kguYa7Po2U [Accessed: 29 April 2020].

Kočović, P., Kočović, Z., \& Kočović, V. 2020. Petar Kočović's COVID-19 statistics and trends [online]. Available at: http://digital-dreams.biz/COVID19/index.php [Accessed: 29 April 2020].

Laplace, P.S. 1774. Mémoire sur la probabilité des causes par les évènements. Mémoires de Mathematique et de Physique, 6, pp.621-656 (in French) [online]. Available at: https://www.biodiversitylibrary.org/item/86068\#page/7/mode/1up [Accessed: 1 May 2020].

Mann, P.S. 1994. Statistics for Business and Economics. Hoboken, New Jersey: Willey.

-McKinsey \& Company. 2020. COVID-19: briefing Materials [online]. Available at: https://www.mckinsey.com/ /media/mckinsey/business \%20functions/risk/our\%2 Oinsights/covid\%2019\%20implications\%20for\%20business/covid\%2019\%20april \%2013/COVID-19-facts-and-insights-april-24.ashx [Accessed: 12 April 2020].

Reséndiz-Muñoz, J., Corona-Rivera, M.A., Fernández-Muñoz, J.L., ZapataTorres, M., Márquez-Herrera, A., \& Ovando-Medina, V.M. 2017. Mathematical model of Boltzmann's sigmoidal equation applicable to the set-up of the RFmagnetron co-sputtering in thin films deposition of $\mathrm{Ba}_{x} \mathrm{Sr}_{1-\mathrm{x}} \mathrm{TiO}_{3}$. Bulletin of Materials Science, 40, pp.1043-1047. Available at: https://doi.org/10.1007/s12034-017-1441-x. 
Stahl, S. 2006. The Evolution of the Normal Distribution. Mathematic Magazine, 79(2), pp.96-113. Available at: https://doi.org/10.1080/0025570X.2006.11953386.

-World Health Organization. 2020. Coronavirus disease (COVID-2019) situation reports [online]. Available at: https://www.who.int/emergencies/diseases/novel-coronavirus-2019/situationreports/ [Accessed: 18 May 2020].

МОНИТОРИНГ КОРОНАВИРУСА COVID-19 ПОДОБНО ПОЛЕТУ САМОЛЕТА ПО ПРИБОРАМ

Петар В. Кочович ${ }^{a}$, Зоран В. Кочович ${ }^{б}$, Владимир П. Кочович ${ }^{\text {в }}$

а Университет Унион «Никола Тесла», Факультет информационных технологий и инжиниринга, г. Белград, Республика Сербия, корреспондент

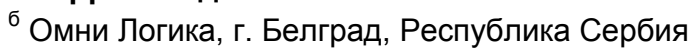

в IGT, г. Белград, Республика Сербия

РУБРИКА ГРНТИ: 27.00.00 МАТЕМАТИКА;

27.43.17 Математическая статистика,

27.43.51 Применение теоретико-вероятностных и статистических методов

ВИД СТАТЬИ: оригинальная научная статья

Резюме:

Введение/цель: Данная команда, в целях эпидемиологического мониторинга за COVID-19 в каждой отдельной стране мира, разработала специальную систему, которая состоит из следующих диаграмм и математических моделей: а) эпидемиологическая кривая, б) гистограмма зараженных людей, в) гистограмма зараженных людей за последних пять дней, г) кривая в двойном логарифмическом масштабе для мониторинга скорости распространения эпидемии, д) эпидемиологическое многопараметровое наблюдение и е) кривые Гаусса и Больцмана (С-кривые). В данной статье эпидемиологический мониторинг за развитием эпидемии представлен подобно полету самолета по приборам.

Методы: Наиболее сложной моделью является вычисление усеченной кривой Гаусса. В данной связи модель подробно представлена в этой статье. Кроме того, существует совпадение во времени между кривой Гаусса и С-кривой. Данные были взяты с официального сайта Всемирной организации здравоохранения. Полный набор данных состоит из кривой Гаусса, двойной кривой в логарифмическом маситабе и эпидемиологической кривой, которые рассматриваются 


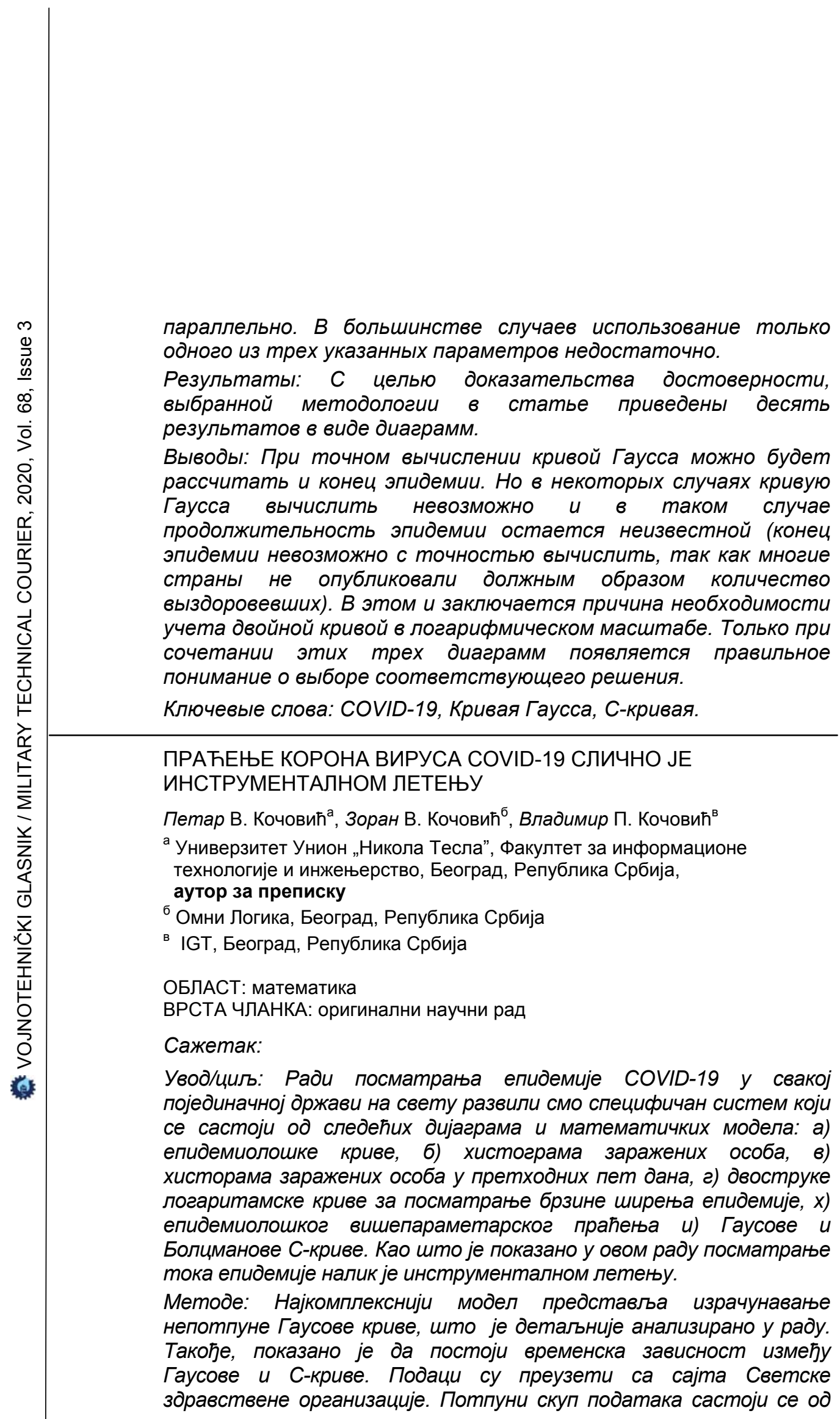


Гаусове криве, двоструке логаритамске криве и епидемиолошке криве, које се посматрају упоредо. Посматрање само једне од назначене три криве у великом броју случајева није довољно.

Резултати: Како би се доказале изабране методологије, рад садржи десетак резултата у облику дијаграма.

Закључак: Када се израчуна Гаусова крива може се доћи до податка о крају епидемије. Међутим, у неким случајевима Гаусова крива се не може израчунати, па крај епидемије није јасан, најчешће зато ито многе државе нису декларисале број опорављених пацијената на адекватан начин. Зато се мора узети у обзир двострука логаритамска крива. Само комбинацијама три дијаграма добија се прави увид у доошење исправних одлука.

Кључне речи: COVID-19, Гаусова крива, С-крива.

Paper received on / Дата получения работы / Датум пријема чланка: 30.04.2020.

Manuscript corrections submitted on / Дата получения исправленной версии работы / Датум достављања исправки рукописа: 18.05.2020.

Paper accepted for publishing on / Дата окончательного согласования работы / Датум коначног прихватања чланка за објављивање: 20.05.2020.

(๐) 2020 The Authors. Published by Vojnotehnički glasnik / Military Technical Courier (www.vtg.mod.gov.rs, втг.мо.упр.срб). This article is an open access article distributed under the terms and conditions of the Creative Commons Attribution license (http://creativecommons.org/licenses/by/3.0/rs/).

(c) 2020 Авторы. Опубликовано в «Военно-технический вестник / Vojnotehnički glasnik / Military Technical Courier» (www.vtg.mod.gov.rs, втг.мо.упр.срб). Данная статья в открытом доступе и распространяется в соответствии с лицензией «Creative Commons» (http://creativecommons.org/licenses/by/3.0/rs/).

(c) 2020 Аутори. Објавио Војнотехнички гласник / Vojnotehnički glasnik / Military Technical Courier (www.vtg.mod.gov.rs, втг.мо.упр.срб). Ово је чланак отвореног приступа и дистрибуира се у складу са Creative Commons licencom (http://creativecommons.org/licenses/by/3.0/rs/). 